\title{
NITRIC ACID REQUIREMENT FOR TREATING SLUDGE (U)
}

\author{
by C.W. Hsu
}

Westinghouse Savannah River Company

Savannah River Site

Aiken, South Carolina 29808

Other Authors:

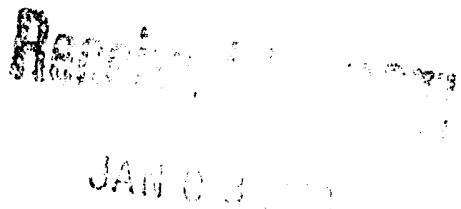

This paper was prepared in connection with work done under Contract No. DE-AC09-89SR18035 with the U. S. Department of Energy. By acceptance of this paper, the publisher and/or recipient acknowledges the U. S. Government's right to retain a nonexclusive, royalty-free license in and to any copyright covering this paper, along with the right to reproduce and to authorize others to reproduce all or part of the copyrighted paper. 


\section{DISCLAIMER}

This report was prepared as an account of work sponsored by an agency of the United States Government. Neither the United States Government nor any agency thereof, nor any of their employees, makes any warranty, express or implied, or assumes any legal liability or responsibility for the accuracy, completeness, or usefulness of any information, apparatus, product, or process disclosed, or represents that its use would not infringe privately owned rights. Reference herein to any specific commercial product, process, or service by trade name, trademark, manufacturer, or otherwise does not necessarily constitute or imply its endorsement, recommendation, or favoring by the United States Government or any agency thereof. The views and opinions of authors expressed herein do not necessarily state or reflect those of the United States Government or any agency thereof.

This report has been reproduced directly from the best available copy.

Available to DOE and DOE contractors from the Office of Scientific and Technical Information, P.O. Box 62, Oak Ridge, TN 37831; prices available from (615) 576-8401, FTS 626-8401.

Available to the public from the National Technical Information Service, U.S. Department of Commerce, 5285 Port Royal Rd, Springfield, VA 22161. 
Keywords: DWPF, Nitric Acid Flowsheet, Redox, Hydrogen

Retention Period: Permanent

CC: L. M. Papouchado, 773-A

J. T. Carter, 704-1T

L. F. Landon, 704-T

M. J. Plodinec, 773-A

C. T. Randall, 704-T

A. S. Choi, 704-1T

SRTC Records (4)

September 4, 1992

TO: E. W. HOLTZSCBEITER, 773-A

FROM: C. W. BSU, 704-1T

\section{DEFENSE WASTE PROCESSING FACIIITY NITRIC ACID REOUIRFMTNT FOR TRMATIKG STUDGE (U)}

\section{SUMMARY}

The hydroxylamine nitrate (HAN) precipitate hydrolysis process produces sufficient oxidant (nitrate) such that the resulting blend of formic acid treated sludge and the aqueous product from hydrolysis (PHA) produces a melter feed of acceptable redox (i.e. $\mathrm{Fe}+2 /$ Total $\mathrm{Fe}<0.33$ ). With implementation of Late Washing (to reduce the nitrite content of the tetraphenyborate slurry produced during In-Tank Precipitation to $0.01 \mathrm{M}$ or less), HAN is no longer required during hydrolysis. As a result, the nitrate content of the melter feed will be reduced greater than an order-of-magnitude and the resulting melter feed produced will be too reducing.

If formic acid treatment of the sludge is retained, it will be necessary to trim the melter feed with an oxidant to attain a proper redox. Rather than trimming the melter feed with an oxidant subsequent to the SRAT cycle in which formic acid is used to acidify the sludge, the Savannah River Technology Center (SRTC) has recommended this be accomplished by conversion to nitric acid addition to the Sludge Receipt and Adjustment Tank (SRAT) in place of formic acid [1]. This memorandum specifies the stoichiometric bases for determining the nitric acid requirement for the SRAT. 


\section{INTRODUCTION}

The current reference flowsheet for treating the sludge slurry from the tank farms in preparation of the melter feed requires the addition of formic acid to the sludge slurry in the SRAT [2]. Formic acid is added to each sludge batch to (1) reduce mercury to the elemental state for subsequent recovery by steam stripping, (2) reduce $\mathrm{MnO}_{2}$ to $\mathrm{Mn}$ (II) ion to mitigate foaming in the melter, (3) destroy nitrite, and (4) neutralize or acidify the sludge to modify the rheology. Formic acid serves as both an acid and a reductant. After sludge digestion with formic acid aqueous hydrolysis product (PHA) is metered into the SRAT and the excess water evaporated. Glass forming frit is then added and the resulting slurry fed to the DWPF glass melter.

This process has produced an acceptable feed for vitrification. Sufficient oxidant (nitrate) accompanies the PHA that is blended with the acidified sludge to produce an acceptable formate/nitrate balance and correspondingly, an acceptable melter feed redox. However, with the abandonment of the HAN process to destroy nitrite in the precipitate hydrolysis process, the nitrate concentration in the melter feed will be greatly reduced and if the formic acid levels in the current DWPF flowsheet are retained, the resulting glass melt will be too reducing and therefore may cause melter problems by precipitating metals and/or metal sulfides during vitrification, thereby reducing melter lifetime.

In order to assure that the melter is operated at the proper redox state of the glass melt it has been proposed that nitric acid be used to substitute part of the formic acid added at SRAT as the source of an acid [1]. The use of nitric acid in the chemical process cell will eliminate the nitrate deficiency resulting from the implementation of Late Washing. An additional benefit to using nitric acid will be a reduction in hydrogen gas production to at least $50 \%$ of the current design basis [3]

Formic acid (or formate) is still needed as a reductant. The revised process operating parameters for the precipitate hydrolysis process will produce sufficient formic acid and formate to reduce mercury and manganese dioxide in the sludge [3]. The sources of acids in the new proposed flowsheet are nitric acid added at SRAT and formic acid in the incoming PHA. Minimum acid requirement is very similar to that defined earlier for the formic acid requirement and the stoichiometric basis for determining the nitric acid requirement are described in this report.

\section{MAJOR CHFMICAI REACTIONS}

Acid-Base Neutraligation Reactions

$$
\begin{array}{ll}
\mathrm{Na}^{+} \mathrm{OH}^{-}+\mathrm{H}^{+} \longrightarrow \mathrm{Na}^{+}+\mathrm{H}_{2} \mathrm{O} \\
\mathrm{K}^{+} \mathrm{OH}^{-}+\mathrm{H}^{+} \longrightarrow \mathrm{K}^{+}+\mathrm{H}_{2} \mathrm{O}
\end{array}
$$




$$
\begin{array}{ll}
\mathrm{Ca}(\mathrm{OH})_{2}+\mathrm{H}^{+} \longrightarrow \mathrm{Ca}^{++}+\mathrm{H}_{2} \mathrm{O} \\
\mathrm{Ba}(\mathrm{OH})_{2}+\mathrm{H}^{+} \longrightarrow \mathrm{Ba}^{++}+\mathrm{H}_{2} \mathrm{O} \\
\mathrm{Mg}(\mathrm{OH})_{2}+\mathrm{H}^{+} \longrightarrow \mathrm{Mg}^{++}+\mathrm{H}_{2} \mathrm{O} \\
\mathrm{CaCO}_{3}+2 \mathrm{H}^{+} \longrightarrow \mathrm{Ca}^{++}+\mathrm{H}_{2} \mathrm{O}+\mathrm{CO}_{2} \\
\mathrm{Na}_{2} \mathrm{CO}_{3}+2 \mathrm{H}^{+} \longrightarrow 2 \mathrm{Na}^{+}+\mathrm{CO}_{2}+\mathrm{H}_{2} \mathrm{O}
\end{array}
$$

All these reactions are $100 \%$ complete at the end of acid addition to the SRAT and the subsequent reflux period.

\section{Reaction rith Sodium Nitrite}

Two competing reactions probably occur at the same time. The first one is a nitrous acid decomposition reaction.

$$
\begin{array}{ll}
2 \mathrm{H}^{+}+2 \mathrm{NO}_{2}^{-} \longrightarrow & 2 \mathrm{HNO}_{2} \\
3 \mathrm{HNO}_{2} & \mathrm{HNO}_{3}+2 \mathrm{NO} \\
\mathrm{NO}_{2}^{-}+\mathrm{HNO}_{3} \longrightarrow \mathrm{HNO}_{2} \\
\text { overall, } \\
2 \mathrm{H}^{+}+3 \mathrm{NO}_{2}^{-} \longrightarrow \mathrm{NO}_{3}^{-}+2 \mathrm{NO}+\mathrm{H}_{2} \mathrm{O}
\end{array}
$$

This implies that for each mole of nitrite, 0.67 mole of nitric or formic acid will be required.

Another possible reaction is,

$$
2 \mathrm{H}^{+}+2 \mathrm{NO}_{2}^{-}+\mathrm{HCOOH} \longrightarrow \mathrm{CO}_{2}+2 \mathrm{H}_{2} \mathrm{O}+2 \mathrm{NO}
$$

According to this reaction two moles of either nitric acid or formic acid in addition to another mole of formic acid will be required for each mole of nitrite. The IDMS experience indicates that much less formic acid is needed to completely destroy the nitrite during the formic acid demonstration runs. Therefore, we recommend that 0.25 mole of formic acid and an additional 0.5 mole of nitric acid or formic acid be used for each mole of nitrite.

\section{Beduction of $\mathrm{MnO}_{2}$}

$$
\mathrm{MnO}_{2}+\mathrm{HCOOH}+2 \mathrm{H}^{+} \longrightarrow \mathrm{CO}_{2}+\mathrm{Mn}^{++}+2 \mathrm{H}_{2} \mathrm{O}
$$


Melter experience in the past indicated that significant foaming in the melter would not occur when this reaction is approximately $50 \%$ completed. However, lower yield may also be satisfactory. We recommend that $40 \frac{8}{8}$ yield be used for calculational basis.

\section{Reduation of RaO}

$\mathrm{HgO}+\mathrm{HCOOH} \longrightarrow \mathrm{Hg}+\mathrm{H}_{2} \mathrm{O}+\mathrm{CO}_{2}$

The yield for this reaction is $100 \%$.

Listed in Table 1 are the proposed changes of the stoichiometry to reflect the actual yields.

\section{ACID REOUIREMENT}

The following methodology is recommended to determine the quantity of nitric acid to be added to the SRAT:

(1) Based on the stoichiometry listed in Table 1 (column 4), calculate the moles of formic acid required to decompose the nitrite, reduce the $\mathrm{MnO} 2$ to $\mathrm{Mn}^{++}$and reduce the $\mathrm{HgO}$ to $\mathrm{Hg}^{\circ}$. Fornic acid here is the reductant for treating the sludge.

(2) Based on the stoichiometry listed in Table 1 (column 3), calculate the additional moles of acid required based on the contents of key components in the alkaline sludge slurry batched to the SRAT. This is the acid requirement for the sludge slurry batch. Either formic acid in the incoming $\mathrm{PHA}$ or nitric acid satisfies this requirement.

(3) Calculate the total amount (moles) of formic acid in the PHA to be blended with the sludge slurry batch.

(4) Obtain the balance of the acid requirement by subtracting (3) from the sum of (1) and (2). This is the acid requirement to be satisfied with nitric acid.

(5) Based on the concentration of nitric acid to be used, calculate the volume of nitric acid to be added to the SRAT.

\section{MFITER FFED REDOX ITMIT}

The current redox limit for the melter feed is $\leq 0.33\left(\mathrm{Fe}^{+2} /\right.$ Total $\mathrm{Fe})$. Studies are currently in progress to determine if the increased catalyst (copper) requirement in precipitate hydrolysis presents a copper solubility concern in the waste glass at the current redox limit. If the results of these studies necessitate lowering the current redox limit, the nitric acid stoichiometric 
bases will be appropriately amended to ensure sufficient oxidant is added at the SRAT to meet the revised redox constraint.

\section{CAICUIATIONAT ALGORITRMS}

Calculational algorithms will be developed to enable determination of the nitric acid requirement for the SRAT. These algorithms will be transmitted to DWPF by separate transmittal.

\section{BFERBENCES}

(1) E. W. Holtzscheiter, "Nitric Acid Flowsheet - Defense Waste Processing Facility (U)", WSRC-RP-92-1003TL, August 20, 1992

(2) C. W. Hsu, "Formic Acid requirement in the DWPF Chemical Processing Cell (U)", WSRC-RP-92-554, July 5, 1990.

(3) SRAT off-Gas Task team, "Flammability Control Design Criteria for DWPF Radioactive Operation (U) ", WSRC-RP-92-920 (Rev. 1), October 4, 1991.

(4) I. F. Landon, "DWPF Integrated Cold Runs - Revised Technical Bases for Precipitate Hydrolysis (U)", WSRC-RP-92-737, May 27, 1992 . 


\section{TABLE 1 PROPOSED STOICHIOMETRY}

\begin{tabular}{|c|c|c|c|}
\hline Beactants & Yields & $\begin{array}{l}\text { Acid } \\
\text { Beguireda, b }\end{array}$ & $\frac{\text { Bcoog }}{\text { Requireda }}$ \\
\hline $\begin{array}{l}\text { Alkali Metal } \\
\text { Hydroxide } \\
\text { (NaOH, } \mathrm{KOH})\end{array}$ & $100 \%$ & 1.0 & \\
\hline $\begin{array}{l}\text { Alkali Earth } \\
\text { Metal Hydroxide } \\
{\left[\mathrm{Ca}(\mathrm{OH})_{2}, \mathrm{Ba}(\mathrm{OH})_{2},\right.} \\
\left.\mathrm{Mg}(\mathrm{OH})_{2}\right]\end{array}$ & $100 \%$ & 2.0 & \\
\hline Carbonate $\left(\mathrm{CO}_{3}=\right)$ & $100 \%$ & 2.0 & \\
\hline Nitrite $\left(\mathrm{NO}_{2}^{-}\right)$ & $100 \%$ & 0.50 & 0.25 \\
\hline $\mathrm{MnO}_{2}$ & 408 & 0.8 & 0.40 \\
\hline $\mathrm{HgO}$ & $100 \%$ & & 1.0 \\
\hline
\end{tabular}



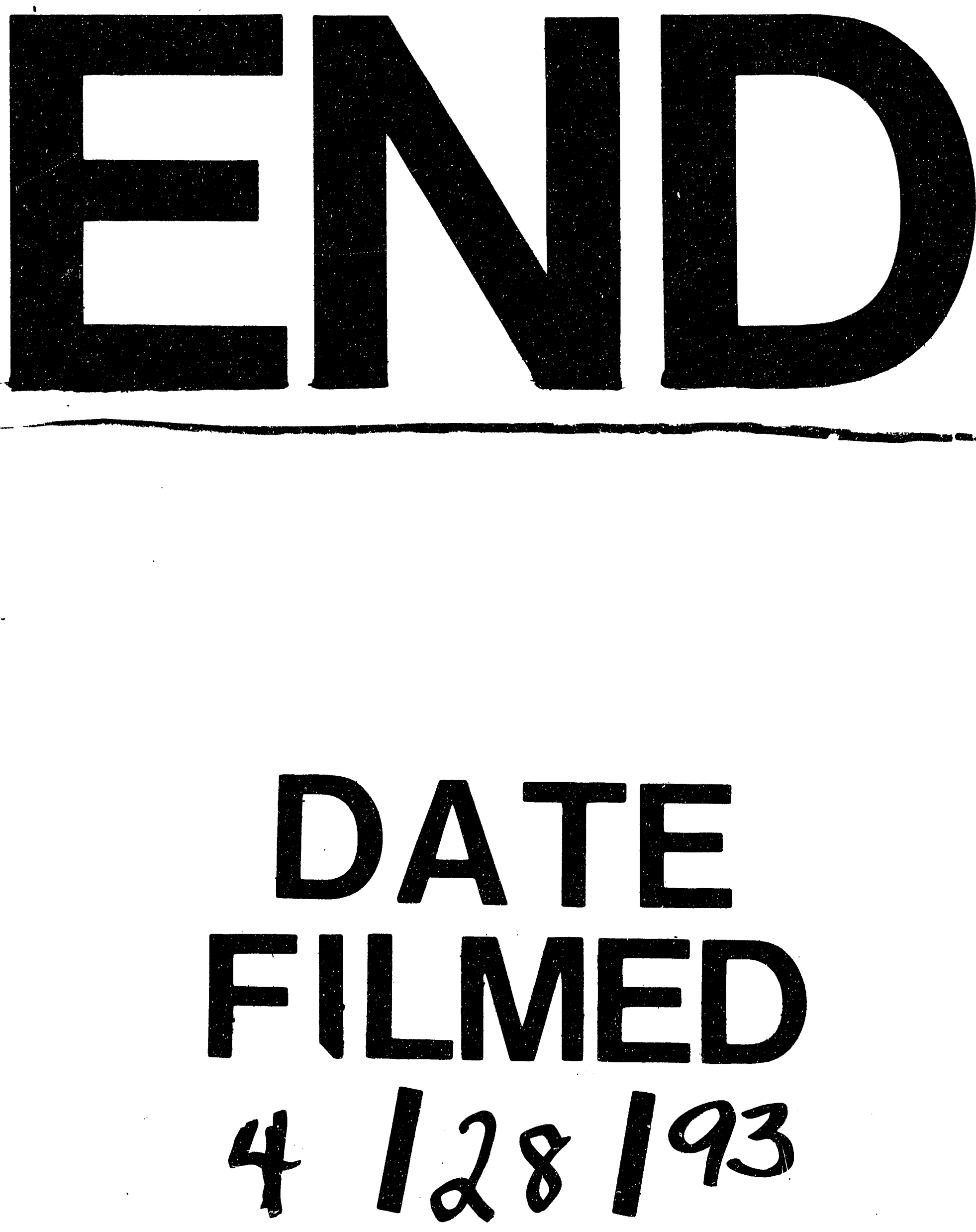
